\title{
Using Decision Support for Water Quality Improvement Planning: the CAPER DSS
}

\author{
$\underline{\text { R.A. Kelly }}$ \\ isNRM Pty Ltd, PO Box 8017 Trevallyn TAS 7250 \\ Email: rebecca@isnrm.com.au
}

\begin{abstract}
Water Quality Improvement Plans (WQIP) are an ecosystem-based approach to integrated water cycle management. They aim to integrate the best available science for decision making coupled with a strong participatory approach. A WQIP is a comprehensive plan for water quality protection and improvement in the face of pressures from future development. Plan recommendations are developed in consultation with the community to ensure they are feasible, cost effective and will achieve the environmental outcomes required.

This paper describes the Catchment Planning and Estuary Response (CAPER) Decision Support System (DSS) which has been designed to support the development of these plans. To date this approach has been or is in the process of being used in the development of ten water quality improvement plans. CAPER integrates metamodels of more detailed catchment and receiving water quality models such as the Source Catchments model, MUSIC model and DELPH-3D model with other empirical and literature based approaches to allow testing of the impact of alternative future land use and land management options. An easy-to-use interface has been developed to allow development of scenarios and exploration of the impacts of alternative options. This paper describes the generic CAPER approach and its application to developing WQIPs for several case studies in the Northern Territory, NSW and Tasmania.
\end{abstract}

Keywords: Decision support system, CAPER, water quality improvement plan 


\section{INTRODUCTION}

Water Quality Improvement Plans are a planning process developed by the Federal Government through its Coastal Catchments Initiative. A Water Quality Improvement Plan (WQIP) provides an ecosystem based approach to integrated water cycle management, supported by science. WQIPs have already been developed for 12 major estuary systems Australia wide, including the Great Lakes in New South Wales, Derwent estuary, Botany Bay, Moreton Bay and the Swan Canning estuary. WQIP are designed to:

- $\quad$ engage state, local government, NRM groups and cooperatively prepare a WQIP and implement interim projects;

- resolve major impediments to Water Quality planning and management through a catchment management based approach;

- $\quad$ address the key priority threats to water quality and environmental flows, and establish methods to continuously improve management knowledge and systems; and,

- $\quad$ establish governance arrangements that ensure all relevant stakeholders are party to WQIP implementation (adapted from Dept. of Environment, 2011).

WQIPs generally follow the same basic process although there are differences in the focus between different plans. Development of a plan usually involves:

- $\quad$ capturing current knowledge;

- undertaking further investigations to fill key knowledge gaps (typically development of models in Source Catchment, a Receiving Water Quality Model, MUSIC, and other studies on system ecology or the feasibility of various management actions);

- consulting with key stakeholders and the community to identify environmental values;

- development of a Decision Support System (DSS) to integrate various models and studies and to allow the testing of alternative management scenarios and their impacts on catchment and estuary water quality as well as cost;

- developing water quality targets in terms of both loads and concentrations that link management practice, catchment water quality and estuary ecosystem condition targets;

- identifying appropriate management actions in consultation with key stakeholders required to meet targets and costing these; and,

- developing an implementation plan as well as a plan for future modelling and monitoring (adapted from Queensland Government, 2008).

While the original WQIP were rolled out as part of the Federal Government's Coastal Catchments Initiative, the process has proven to be successful at engaging the broad range of stakeholders required to manage catchment and estuary water quality. As such, further WQIP have been developed as collaborative efforts between key stakeholders in other estuaries such as Sydney Harbour and the Tamar estuary. The Catchment Planning and Estuary Response (CAPER) DSS has been developed and implemented through 10 case studies to support the development of WQIPs. This paper describes the CAPER DSS and the way it has adapted and evolved to support the development of WQIP for very different estuaries.

\section{WHAT IS THE CAPER DSS?}

The CAPER DSS is a decision support system designed to:

- integrate information from catchment water quality models, receiving water quality models, MUSIC modelling, literature and expert opinion;

- provide information on the costs and benefits associated with different management options;

- allow assessment of the trade-offs associated with different land use and land management options in the catchment to be assessed;

- $\quad$ run scenarios fast to allow for quick comparison of alternatives (less than two minutes per run) which allows live runs during key stakeholder workshops; 
- be accessible to nontechnical users (ie people without any modelling skills or background) and stakeholders; and,

- provide a memory of project methods and outputs and make models more accessible to stakeholders, managers and policy makers.

The CAPER DSS delivers on these needs by using a generic modelling platform and an easy-to-use interface shell that can be rapidly tailored to meet the needs of new applications. The system has been designed to include 'soft' data such as text descriptions, photos and maps. It contains a significant amount of contextual information and provides

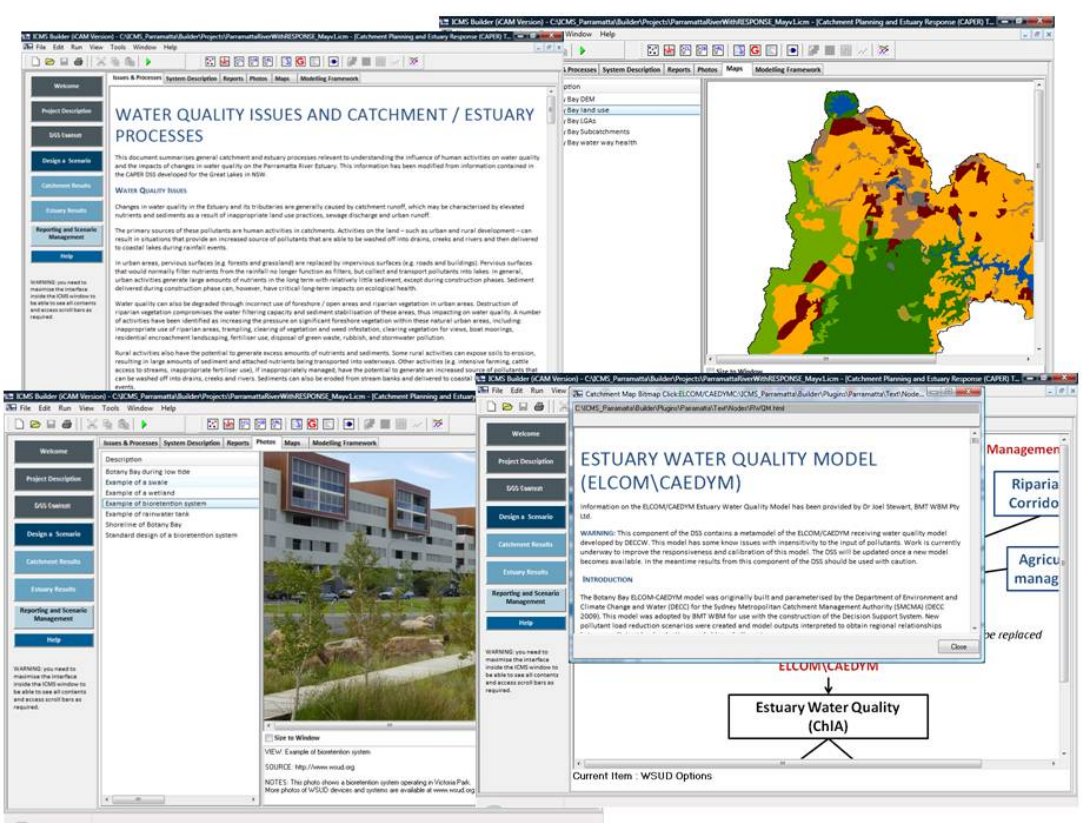

Figure 1. Examples of the contextual information provided in the CAPER DSS - including information on processes, maps, photos and descriptions of the modelling components and their limitations. internal documentation of assumptions and models used in each application to make these available to people without significant modelling skills (see Figure 1).

The CAPER DSS has been modified and adapted for each of the catchments and estuaries that it has been developed for. It is built on an integrated model that pulls together components to represent different parts of the management action-catchment-estuary system. Different components are included in each case study to allow for the specific pollutant sources and impacts of interest to be considered. The interface has also been continuously modified to meet the changing needs of different applications. As an example, Figure 2 shows the integrated model structure underlying the Parramatta River CAPER DSS. This is the latest iteration of CAPER DSS, having been modified to include Bayesian Network (BN) based freshwater and estuarine ecological response models. The components included in previous versions of the CAPER DSS are:

- A metamodel of a catchment water quality model (typically the Source Catchments model but also previously the AnnAGNPS model) which uses a modelling scale consisting of intersections of subcatchments and local government areas (LGAs) to allow scenarios to be created, and results viewed, on either basis. This model typically outputs flow, total suspended sediments (TSS), total nitrogen (TN) and total phosphorus (TP) for each of the subcatchment - LGA combination. More recent applications have also included pathogens such as enterococci and E.coli.

- A metamodel of the MUSIC model to allow various water sensitive urban design (WSUD) treatment train options to be investigated.

- An empirical model of riparian vegetation and its impacts on pollutant export based on the scientific literature.

- An empirical model of sewer overflows based on data provided by the relevant water authority.

- An empirical model of sewage treatment plant (STP) loads based on data provided by the relevant water authority.

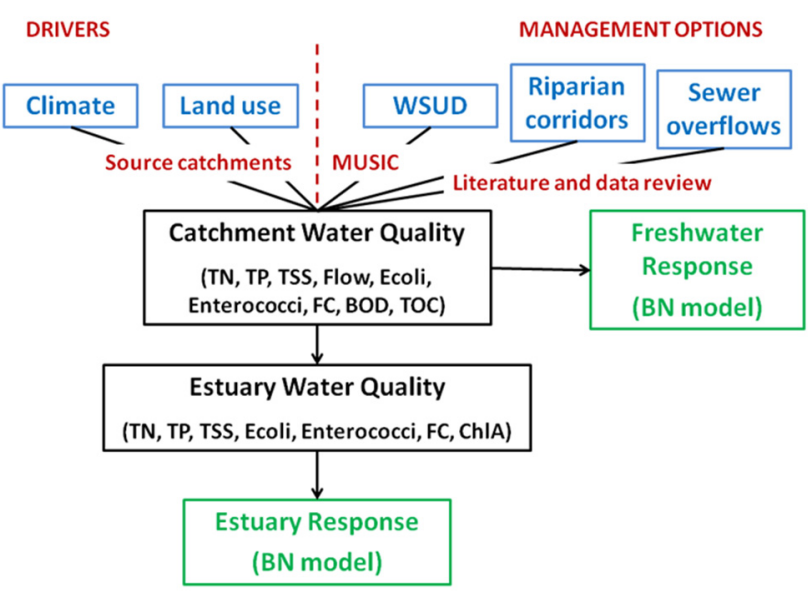

Figure 2. Conceptual model underlying the Parramatta River CAPER DSS. 
- An empirical model of aquaculture operations.

- Models of the impact of management actions on pollutant loads and concentrations using empirical and literature information sources including: riparian vegetation, restricting stock access to stream, improved fertilizer management, groundcover management, irrigation management and the management of drains and laneways in dairy areas.

- A metamodel of a receiving water quality model that estimates the impacts of changes in pollutant loads to the estuary on estuary water quality using a tracer approach to produce map based spatial impacts.

- Two BN Response models capturing the impact of changes in water quality on freshwater and estuarine ecological responses to changes in water quality and other actions and drivers (such as dredging or the construction of seawalls). BN Response models have only been applied in the Sydney Harbour applications.

Typical scenarios that are able to be considered by the CAPER DSS are:

- Changes in catchment land use such as urban expansion or agricultural intensification.

- Revegetation of the riparian zone including buffers of different lengths, width and consisting of different vegetation types (trees only or mixed grass and trees).

- WSUD - a broad range of treatment trains have been included in previous versions including devices such as wetlands, bioretention systems, swales, gross pollutant traps and rainwater tanks.

- Changing the frequency and concentration of sewer overflow events relative to different flow thresholds including removing specific sewer overflow points.

- Changes to STP operations including upgrades, closures and the impacts of increased population.

- Agricultural and grazing management including changes to groundcover, stock access to streams, irrigation and fertilizer regimes.

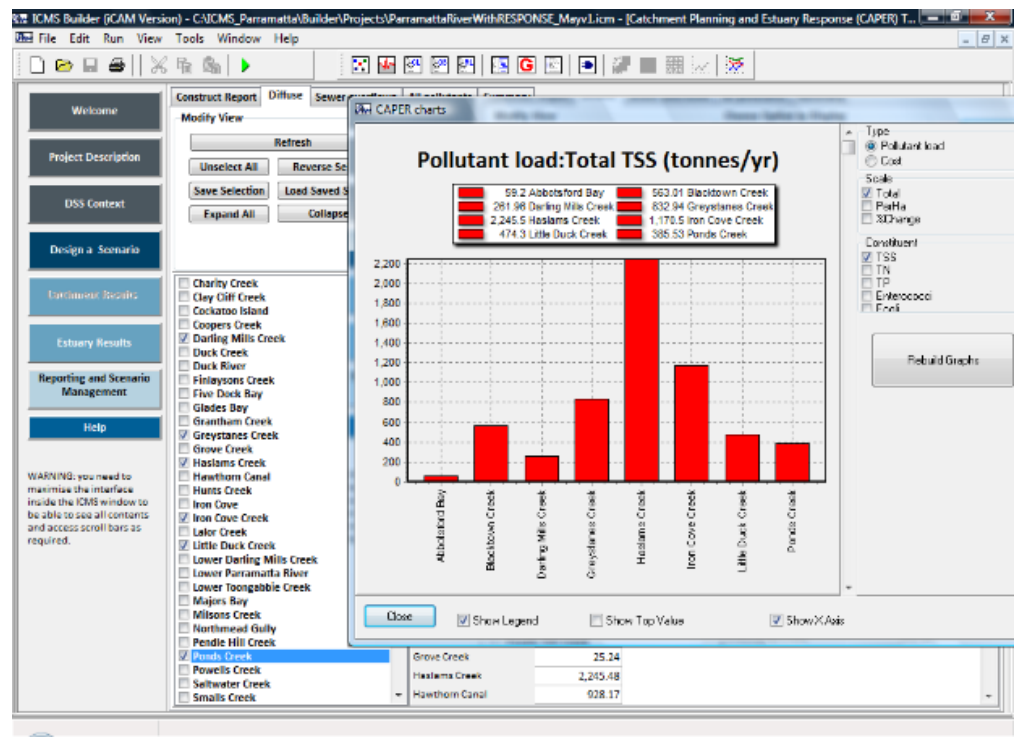

Figure 3. Diffuse pollutant loads for selected subcatchments in a chart format.

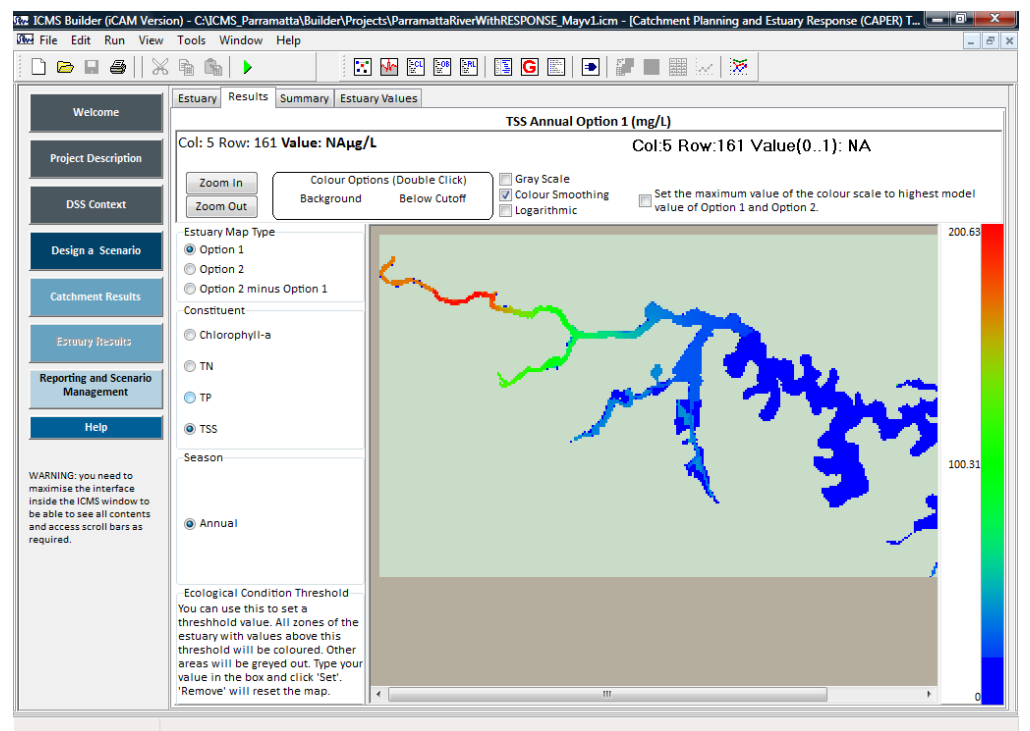

Figure 4. Colour map of water quality in the Parramatta River estuary.

Results are provided in the

interface through tables, graphs and maps (Figure 3). Data can also be exported from the DSS to csv files for use outside the system. The interface produces diffuse and point source, such as STP, sewer overflows or aquaculture, loads for pollutants such as TSS, TN, TP and enterococci. Where a receiving water quality model is available, impacts on estuary water quality are also displayed as a coloured map (Figure 4), and summary table of percentile values and probability of exceeding condition thresholds in zones of the estuary. The Sydney 
Harbour CAPER DSS also impacts on freshwater and estuary response nodes such as invertebrates, fish and birds as likelihoods of various discrete state outcomes.

\section{WATER QUALITY IMPROVEMENT PLANS SUPPORTED BY THE CAPER DSS}

The CAPER DSS has been developed and adapted over the course of 10 WQIPs. This section looks at the major components and differences between these DSS and shows how the DSS has been flexible enough to adapt to very different catchment and estuary systems. Table 1 contrasts several of the CAPER DSS that have been developed.

As can be seen in Table 1, while the same basic CAPER DSS architecture and code has been used in all these DSS, the components of the DSS and its capabilities in terms of scenarios are very different. The DSS approach has also been flexible enough to build on very different underlying detailed models such as AnnAGNPS, Source Catchments, DELPH3D and the ELCOM/CAEDYM. Application have included very different management modules depending on the major sources of pollutants in each catchment.

It is possible to redevelop the software for any catchment management action where information can be obtained on its impact on catchment loads. In theory, any underlying detailed model could be used as the basis of the metamodels underlying the DSS.

Table 1. Comparison of previous applications of the CAPER DSS.

\begin{tabular}{|c|c|c|c|c|c|}
\hline Element & $\begin{array}{l}\text { Great Lakes - } \\
\text { Myall, Wallis } \\
\text { and Smiths lakes }\end{array}$ & Botany Bay & Darwin Harbour & Sydney Harbour & Tamar estuary \\
\hline Climate & Temperate & Temperate & Tropical & Temperate & Temperate \\
\hline Spatial scale & $\begin{array}{l}\text { Subcatchment } \\
\text { only }\end{array}$ & $\begin{array}{l}\text { Intersection of } \\
\text { subcatchment and } \\
\text { LGA }\end{array}$ & $\begin{array}{l}\text { Intersection of } \\
\text { subcatchment and } \\
\text { LGA }\end{array}$ & $\begin{array}{l}\text { Intersection of } \\
\text { subcatchment and } \\
\text { LGA }\end{array}$ & $\begin{array}{l}\text { Intersection of } \\
\text { subcatchment and } \\
\text { LGA }\end{array}$ \\
\hline $\begin{array}{l}\text { Scenario } \\
\text { options }\end{array}$ & $\begin{array}{l}\text { Land use change } \\
\text { Climate change } \\
\text { WSUD } \\
\text { Groundcover } \\
\text { management } \\
\text { Nutrient } \\
\text { management } \\
\text { Stock access to } \\
\text { streams } \\
\text { Riparian } \\
\text { revegetation }\end{array}$ & $\begin{array}{l}\text { Land use change } \\
\text { Climate change } \\
\text { WSUD } \\
\text { Riparian revegetation } \\
\text { Generic agricultural } \\
\text { management option }\end{array}$ & $\begin{array}{l}\text { Land use change } \\
\text { Climate change } \\
\text { WSUD } \\
\text { Riparian } \\
\text { revegetation } \\
\text { Generic } \\
\text { agricultural } \\
\text { management } \\
\text { option } \\
\text { WWTP upgrades, } \\
\text { closures and } \\
\text { population growth }\end{array}$ & $\begin{array}{l}\text { Land use change } \\
\text { Climate change } \\
\text { WSUD } \\
\text { Riparian } \\
\text { revegetation } \\
\text { Generic } \\
\text { agricultural } \\
\text { management } \\
\text { option } \\
\text { Sewer overflow } \\
\text { management } \\
\text { PLUS in ERM } \\
\text { Estuary dredging } \\
\text { Mechanical } \\
\text { removal of } \\
\text { mangroves, } \\
\text { saltmarsh and } \\
\text { seagrass } \\
\text { Seawall } \\
\text { construction } \\
\text { Ferries \& boats } \\
\text { PLUS in FRM } \\
\text { Dredging } \\
\text { Concrete } \\
\text { channels \& pipes } \\
\text { Barriers to fish } \\
\text { passage }\end{array}$ & $\begin{array}{l}\text { Land use change } \\
\text { Urban } \\
\text { management } \\
\text { Dairy } \\
\text { management } \\
\text { Grazing } \\
\text { management } \\
\text { Crop management } \\
\text { Production forest } \\
\text { management } \\
\text { WWTP upgrades, } \\
\text { closures and } \\
\text { population growth } \\
\text { Salmon farming - } \\
\text { scale, additional } \\
\text { farm }\end{array}$ \\
\hline $\begin{array}{l}\text { Catchment } \\
\text { model }\end{array}$ & AnnAGNPS & Source Catchments & $\begin{array}{l}\text { Source } \\
\text { Catchments }\end{array}$ & $\begin{array}{l}\text { Source } \\
\text { Catchments }\end{array}$ & $\begin{array}{l}\text { Source } \\
\text { Catchments }\end{array}$ \\
\hline Estuary model & $\begin{array}{l}\text { Prognosis } \\
\text { software - } \\
\text { Sanderson } \\
(2007)\end{array}$ & ELCOM/CAEDYM & $\begin{array}{l}\text { RMA2 } \\
\text { hydrodynamic and } \\
\text { the RMA11 water } \\
\text { quality model }\end{array}$ & DEPLH3D & $\begin{array}{l}\text { RMA10s for } \\
\text { flows and } \\
\text { sedimentation and } \\
\text { RMA11 water } \\
\text { quality }\end{array}$ \\
\hline $\begin{array}{l}\text { WQIP/WQPP } \\
\text { references }\end{array}$ & $\begin{array}{l}\text { Great Lakes } \\
\text { Council (2009) }\end{array}$ & $\begin{array}{l}\text { Kelly and } \\
\text { Dahlenburg (2011) }\end{array}$ & DLRM (2014) & LLS (2015) & $\begin{array}{l}\text { Kelly et al., } \\
(2015)\end{array}$ \\
\hline
\end{tabular}




\section{AN EXAMPLE: USING THE CAPER DSS TO DEVELOP A LOAD TARGET FOR THE TAMAR ESTUARY AND ESK RIVERS CATCHMENT}

The Tamar River estuary is located in North Eastern Tasmania. It extends on a south-east to north-west axis for approximately $70 \mathrm{~km}$ following a meandering path from Launceston to the Bass Strait at Low Head on Tasmania's north coast. The river is formed through the convergence of the North Esk and South Esk rivers at Launceston. The South Esk basin (the longest river in Tasmania at $214 \mathrm{~km}$ draining the Macquarie, Meander and South Esk sub-catchments) is the main source of freshwater flows and sediments to the Tamar; the North Esk is considerably smaller. The topology of the catchment varies from low hills and plains characterised by agriculture in the Northern Midlands, to plateaus of the Western Tiers, Ben Lomond and Eastern Highlands. The Tamar estuary and Esk rivers (TEER) catchment drains an area of approximately $10,000 \mathrm{~km}^{2}$ or 15 percent of the state of Tasmania. Nine local government areas are responsible for this region

The CAPER DSS has been used to develop the TEER WQIP. As part of this WQIP a set of load targets have been derived for current and future land use and population. The first scenario, using current land use, applies levels of adoption of various management practices as follows:

Urban management:

- $\quad 8 \%$ of urban areas treated with large scale WSUD devices, assuming both upfront and maintenance incentives are provided.

- $\quad 25 \%$ of urban areas are treated with household scale WSUD devices such as rainwater tanks, assuming both incentives and education are provided.

- $\quad 95 \%$ of building sites adopt and maintain effective erosion and sediment control.

Grazing management:

- $25 \%$ of streams have limited stock access to streams, assuming maintenance and upfront incentives are provided.

- $\quad 75 \%$ of remaining unvegetated stream sections have a 5 metre vegetated riparian, assuming upfront and maintenance incentives are provided.

- Groundcover levels are raised to the $90^{\text {th }}$ percentile for any areas currently below

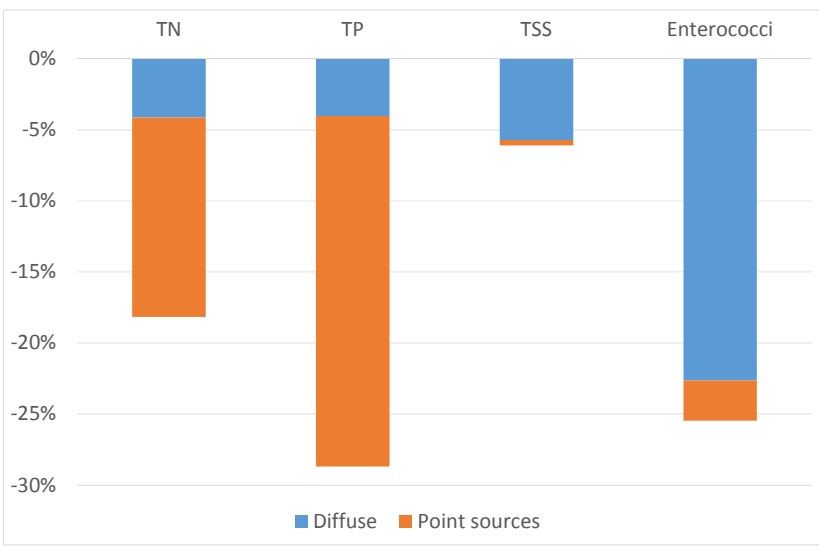

Figure 5. Load target decreases in pollutant loads from diffuse and point sources. this level, corresponding to $84 \%$ in summer and $89 \%$ in winter.

Crop management:

- $50 \%$ of areas with bare soil greater than $20 \%$ in summer and $10 \%$ in winter reduce bare soil to these levels.

- $10 \mathrm{~m}$ riparian buffers are implemented on $10 \%$ of steam length that is currently unvegetated.

- $\quad 95 \%$ of farmers adopt controlled release fertilisers.

Dairy management:

- $\quad$ Stock are excluded from $90 \%$ of streams.

- $100 \%$ of dairy farms have sufficient effluent storage.

Sewage treatment assuming the current preferred option:

- $\quad$ Stage 1 - existing plants at Hoblers Bridge, Norwood, Newnham, Prospect, Riverside and Legana are decommissioned. Effluent currently treated at these plants is redirected to a new STP collocated with the current plant at $\mathrm{Ti}$ Tree bend. In addition to this, $4 \mathrm{ML} /$ day of effluent that currently gets treated at the existing Ti Tree bend STP is also directed to the new plant. Treatment at this plant is assumed to comply with accepted modern technology (AMT) standards agreed to within the sewage industry.

- $\quad$ Stage 2 - the existing STP at Ti Tree bend is upgraded and continues to operate, treating a smaller volume (as outlined above) of effluent than currently. Treatment standards at this plant are also increased to AMT standards.

Feasible levels of adoption for these management actions were derived in consultation with key stakeholders given various assumptions around incentive and education programs. 
Figure 5 shows the impacts on total pollutant loads to the Tamar estuary under the current land use and population scenario. Cumulative impacts are shown separated into contributions from diffuse and point sources. This figure shows that large decreases in nutrients and pathogens can be achieved with significant improvements in sediment loads also possible. Improvements in sediments and pathogen loads are driven by reductions in diffuse source pollutants, whereas nutrient improvements are largely driven by decreases in point source loads. Figure 6 shows the impacts on receiving water quality expected due to these decreases in loads.

This figure shows that the greatest improvements in water quality can be expected in the upper estuary zones, from Launceston to Legana and Legana to Swan Point. This zone is a focus of recreation and amenity values due to its close proximity to Launceston. Relative changes in sediments and pathogens are fairly consistent down the estuary, whereas much larger decreases in nutrients are experienced in the upper estuary than the lower estuary.

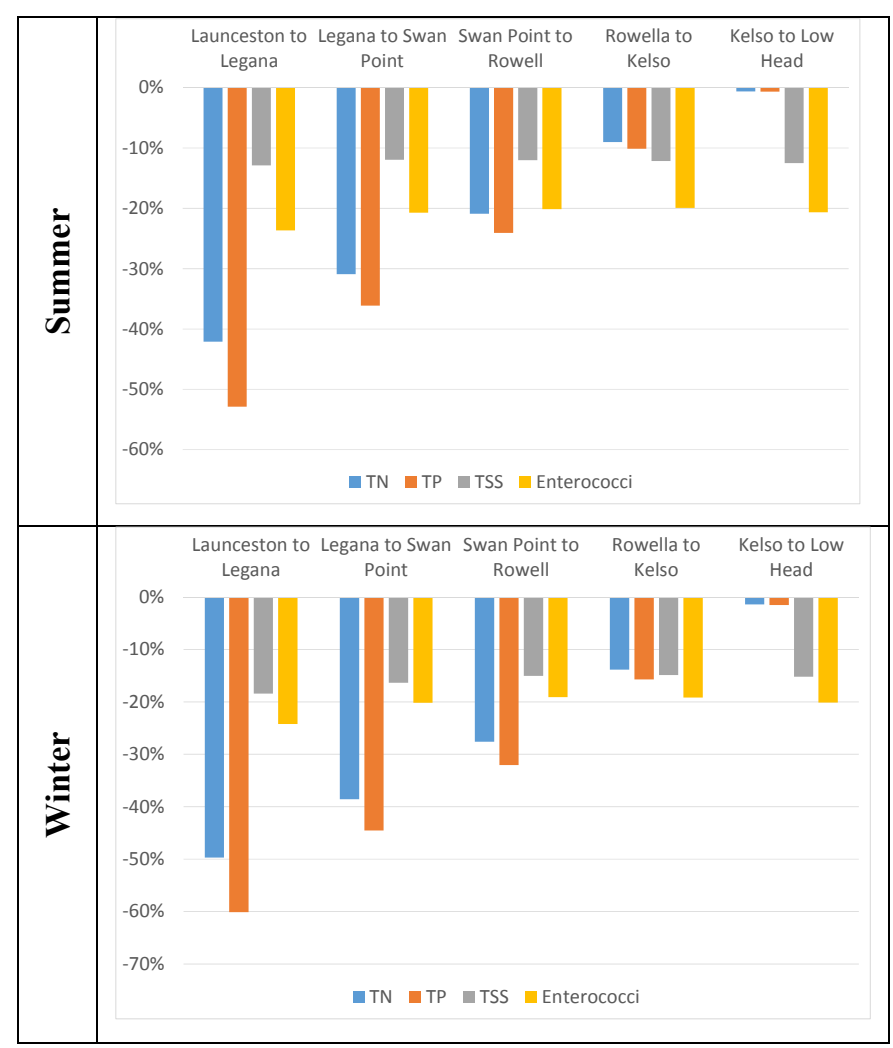

Figure 6. Impacts on average estuary pollutant concentrations in TEER estuary report card zones using current land use scenario.

\section{CONCLUSIONS}

Water Quality Improvement Plans are a very effective process for engaging a broad range of stakeholders in the management of estuary and catchment water Quality. The CAPER DSS has been specifically designed to support development of these plans. It has been implemented for 10 catchments to support development of WQIP. The DSS has proven itself well suited to the task of:

- Designing catchment load targets given their ability to meet desired estuary condition targets;

- Exploring a feasible set of management actions capable of meeting load targets;

- Costing management actions; and,

- Supporting key stakeholders such as Local Governments in their implementation of completed plans.

The DSS is very flexible in allowing a very broad range of management options as well as being able to be built on various detailed base models. Experience in workshops shows that the DSS is very easy to use and can be run and its results understood with minimal support by users with no background in modelling.

\section{REFERENCES}

Dept. of Environment (2011). Water Quality Improvement Plans, http://www.environment.gov.au/water/quality/improvement, accessed June 2011.

DLRM (2014). Darwin Harbour Water Quality Protection Plan, Department of Land Resource Management.

Great Lakes Council (2009). Great Lakes Water Quality Improvement Plan: Wallis, Smiths and Myall Lakes, Forster, NSW.

LLS (2015). Sydney Harbour Water Quality Improvement Plan, Local Land Services.

Kelly, R.A and Dahlenburg, J. (2011). Botany Bay Water Quality Improvement Plan.

Kelly, R.A, A. Locatelli, and M.White (2015). Water Quality Improvement Plan for the Tamar Estuary and Esk rivers, NRM North, Launceston.

Queensland Government (2008). What is involved in developing a WQIP? Regional Natural Resource Management, http://www.regionalnrm.qld.gov.au/policies_plans_legislation/policies_strategies/gbr_water_quality/wqips_what.html Sanderson, B. (2007) Catchment - Estuary Management System, Report prepared for the NSW Department of Environment and Climate Change, Aug 2007. 